\title{
PERSPECTIVES OF INTERCOUNTRY ADOPTIONS IN BRAZIL
}

\section{PERSPECTIVAS DE ADOÇÕES INTERNACIONAIS NO BRASIL}

\section{MARCOS VINÍCIUS TORRES PEIREIRA}

Professor Associado em Direito Civil e Internacional Privado da Faculdade Nacional de Direito, da Universidade Federal do Rio de Janeiro. Advogado. Doutor (2008) e Mestre (2003) em Direito Internacional pela Universidade do Estado do Rio de Janeiro (mviniciusri@hotmail.com).

\section{DIOGO ALEXANDRE DE FREITAS}

Graduando da Faculdade Nacional de Direito (Universidade Federal do Rio de Janeiro), membro do grupo de pesquisa Direito Processual Internacional e Direito Internacional Privado. Bolsista de pesquisa (Projeto Mecanismos De Cooperação Jurídica Internacional e Proteção às Famílias) pelo Programa Institucional de Bolsas de Iniciação Científica (PIBIC) (diogofrreitas@gmail.com).

\section{MARÍLIA SOUSA CRISTO CHAGAS}

Bacharel em Direito pela Faculdade Nacional de Direito (Universidade Federal do Rio de Janeiro). Membro do grupo de pesquisa Direito Processual Internacional e Direito Internacional Privado. Ex-Monitora da disciplina Direito Internacional Privado na Graduação de Direito da UFRJ (mscristchagas@gmail.com).

\begin{abstract}
This present scientific article talks about intercountry and domestic adoption in Brazil, with a focus on private international law. It also describes Brazilian domestic law on domestic and international adoption, as well as conventional law applied in Brazil on this theme. The introduction of this article examines the history of adoption in Brazil and the importance of the Constitution of the Federal Republic of Brazil (1988) for the
\end{abstract}


adoption procedure. It also demonstrated numbers of the intercountry adoption realized by same-sex couples after the significant ruling from the Federal Supreme Court and the Superior Court of Justice. The second part of this study analyzes the nature of the Hague Convention on Protection of Children and Co-operation in Respect of Intercountry Adoption as an instrument of Human Rights protection and the successful international cooperation mechanism. In addition, this article demonstrated and discussed numbers collected during the activities of a research project on "international legal cooperation means applied to family issues in the field of private international law" at the Law School of the Federal University of Rio de Janeiro of intercountry adoption made through the Hague Convention (1993) in Brazil between the period of 1999 and 2017.

KEYWORDS: Private International Law; Intercountry Adoption; Human Rights; The Hague Convention 1993.

\section{RESUMO}

O presente artigo científico discute sobre adoção internacional e nacional no Brasil com o foco em direito internacional privado. O mesmo também descreve a lei interna brasileira no tema de adoção nacional e adoção internacional, ao mesmo que aborda as convenções internacionais que são aplicadas no Brasil com o tema. A introdução do artigo examina o histórico da adoção no Brasil e a importância da Constituição Federal de 1988 para o procedimento de adoção. Ele também demonstra os números de adoção internacional realizadas por casais do mesmo sexo posteriormente à mudança de entendimento do Supremo Tribunal Federal sobre a união estável homoafetiva e o posicionamento do Superior Tribunal de Justiça sobre adoção por casais do mesmo gênero. A segunda parte do artigo analisa a natureza da Convenção de Convenção Relativa à Proteção das Crianças e à Cooperação em Matéria de Adoção Internacional, concluída na Haia, em 29 de maio de 1993 como um instrumento de proteção de direitos humanos e o bem sucedido mecanismo de cooperação internacional. Além disso, o artigo mostra e discute os números coletados durante o projeto em "Mecanismos De Cooperação Jurídica Internacional e Proteção 
às Famílias de adoções" na Universidade Federal do Rio de Janeiro das adoções internacionais realizadas pela Convenção de Haia de 1933 no país entre 1999 e 2017 PALAVRAS-CHAVE: Direito Internacional Privado; Adoção Interpaíses; Direitos humanos; Convenção de Haia, 1993.

\section{INTRODUCTION}

Over the years, the adoption in Brazil has been regulated by several laws. The Brazilian Civil Code 1916 disciplined the adoption based on the Roman principles in which it was destined to provide the continuity of the family, giving the opportunity to the sterile couples to raise children when they could not have one through the biological pathway. Under this perspective, the adoption was only allowed to people who were higher than 50 years old, without legitimate or legitimated offspring, because they could not have children on their own.

Thus, the Brazilian Civil Code 1916 defined some differences between natural and adoptive children, especially in inheritance rights. Besides, ${ }^{1}$ the Minors' Code 1979 only allowed foreigners who had residence or domicile abroad to adopt minors - in the situation of abandonment - in Brazil, through simple adoption. There is an important difference between the simple adoption and full adoption, the first one the child maintains some legal ties with the biological family, although the adoptive relationship typically takes precedence, and the adopters acquire parental authority concerning the child, of the along with the duty of support (VAN LOON, 1993, p.269). This modality of adoption was very precarious since it was revocable. However, the full adoption was applied only to minors in irregular situations, and it also allowed the minors to be admitted to the adoptive family as a legitimate child. The simple adoption is not possible any longer in Brazil ${ }^{2}$ There is just the possibility of full adoption in which the adopted child is wholly integrated into the new family, and the legal bonds between the child and the original family are almost over. 
The concept of adoption became more comprehensive after the promulgation of the Statute on Child and Adolescent (1990). According to Cristiano Chaves de Farias and Nelson Rosenvald (FARIAS, ROSENVALD, 2015), the adoption is an act of love, pushing away the comprehension of adoption with the possibility of giving a child to those who cannot have, as if it were to substitute a frustration of procreation by the usually method.

Concerning intercountry adoption, it emerged in the context of the Second World War due to the alarming number of orphans in European countries and more significant concern for human rights. Until then, the adoption was attached to the domestic legal order. Under this perspective, the countries that did not suffer the consequences of the war have made several agreements and conventions to find a family to these homeless children and adolescents.

It is important to point out that there was a significant increase in the number of the intercountry adoption through these agreements and treaties. For instance, between 1980 and 2000 more than 50,000 children and adolescents were adopted through the United Nations Convention on the Rights of the Child and the 1993 Hague Convention on Protection of Children and Co-operation in Respect of Intercountry Adoption (MARCEDO, 2011).

However, there is no accurate data on intercountry adoption in Brazil during this period. Probably, this lack of information happens because before the Hague Convention 1993 the intercountry adoption was very informal. Fortunately, the scenario changes completely after the Statute on Child and Adolescent (1990). This Statute aims the necessity of looking for the judiciary in order to adopt a child ${ }^{3}$. In general, it is possible to say that before these two instruments approached above, there was a lack of systematic records and absence of a central authority to control the intercountry adoption practices.

Therefore, after the Statute on Child and Adolescent (1990) and the New Adoption Law (BRAZIL, 2009), later on 2009, the profile of international adoption has changed considerably. The creation and consolidation of the state Central Authorities for International Adoption, as well as the Federal Central Authority and the 
implementation of the National Registry of Adoption considerably attenuated this problem that involved international adoption in Brazil.

\section{THE IMPACT OF THE CONSTITUTION OF THE FEDERAL REPUBLIC OF BRAZIL (1988) TO INTERCOUNTRY ADOPTION}

The article 227, $\S 6^{\circ}$, from Constitution of the Federal Republic of Brazil, established the principle of equality between children. It means that no child can be discriminated for being adopted. This understanding is fully compatible with the article 5 of the CFRB 1988 in which it is stipulated the principles of equality. However, before the Constitution 1988, there was an essential difference between the children as the article 332 of Civil Code 1916 established, considering adopted child as illegitimate children.

The CFRB 1988 was also important to encourage the reform of domestic law on international adoption and for the ratification of international treaties on international adoption. It meant a significant change in Brazilian legal order, as it bring in human rights, special provisions for the protection of family life and international legal cooperation. Moreover, the CFRB 1988 granted isonomic treatment for $\mathrm{man} / \mathrm{husband} /$ father and woman/wife/mother, and also for all children, regardless they were born out of wedlock or not to protect the best interest of the child and family. These democratic principles has highlighted on the equal treatment and the presumption of similar responsibilities for male and female adopters, as well as the restriction towards adoption that might place adopted children in a less favorable position than other children.

\subsection{THE RIGHT OF ADOPTION BY SAME-SEX COUPLES}

The possibility for the recognition of same-sex couples in Brazil was other important aspect of the stipulation for the protection of the family in the CFRB 1988 (BRAZIL, 2011) After many of outlying decisions from local jurisdictions and a tremendous pressure of LGBT movement, the Supreme Federal Court made an 
extensive interpretation of the Constitution to guarantee the same rights granted to straight couples to homosexual partners in 2011. However, it was not enough since some courthouses still did not allow same-sex couples to get married.

Thus, after the possibility of conversion of partnerships into marriages and to some favorable decisions of the local jurisdiction in this sense, ${ }^{4}$ the National Council of Justice extended civil marriage to homosexual couples in $2013^{5}$, while prohibiting notaries to discriminate petitioners to marriage by their sex or sexual orientation. It contributed to multiply the cases of adoptions by same-sex couples as isolated decisions in this sense appeared from 2009 on, and a significant ruling from the Federal Supreme Court confirmed it. In 2010 (BRAZIL, 2010), the Superior Court of Justice ascertained that the judge is not allowed to deny same-sex adoption on the ground that the adoption could lead to psychological issues on the children. Furthermore, in 2012, the same Court clarified that it is possible the unilateral adoption of the homosexual partner's child (BRAZIL, 2012). For example, Maria is João's single mother and Leticia's partner. After three years leaving together, Leticia decided to adopt João and Maria agrees to share the motherhood with her, thus after 2012 it is possible according to the STJ.

Under this perspective, one of the most important judgment for LGBT in terms of adoption only occurred in 2015 (BRAZIL, 2015b). The Supreme Federal Court point out that if the homosexual partnerships are already recognized as family, it deserves legal protection, therefore there is no reason to limit adoption, creating obstacles which the law does not provide. Besides, the Supreme Federal Court considers that it is against the Federal Constitution 1988 to create differences between straight couples and homosexual couples on legal standers.

After that the Superior Court of Justice claimed that it is possible a homosexual person to be eligible and suited to adopt regardless the age of the child (BRAZIL, 2015a).

These understandings have an enormous impact on reality, as it is possible to see on numbers of intercountry conducted in the State of Rio de Janeiro before and 
after 2010. The intercountry adoptions by same-sex couples start to appear just in 2010 in Brazil as an effect of the significant decision from the Supreme Federal Court in 2009. It happens because, before 2009, it was not possible for same-sex couples to adopt in Brazil since the intercountry adoptions by same-sex couples were considered "manifestly contrary to its public policy. ${ }^{6}$ The table below shows the numbers of intercountry adoptions in the State of Rio de Janeiro:

\begin{tabular}{|c|c|c|c|}
\hline $\begin{array}{c}\text { State of } \\
\text { Rio De Janeiro }\end{array}$ & \multicolumn{3}{|c|}{ Prospective Parents } \\
\cline { 2 - 4 } & Individual & Straight couples & Same-sex couples \\
\hline 2009 & 5 & 31 & 0 \\
\hline 2010 & 0 & 27 & 3 \\
\hline 2011 & 2 & 48 & 0 \\
\hline 2012 & 1 & 15 & 2 \\
\hline 2013 & 0 & 12 & 0 \\
\hline 2014 & 0 & 7 & 3 \\
\hline 2015 & 0 & 17 & \\
\hline 2016 & 0 & 7 & \\
\hline & & & \\
\hline & & & \\
\hline
\end{tabular}

Nonetheless, it is important to point out that there were adoptions by samesex couples before 2009 in Brazil. In general, regardless the procedure were made by the couple, just one person could be the legal representative as father or mother (OLIVEIRA, 2017). Many legal problems could arise through this irregular procedure such as inheritance rights and the right to raise the child when the parents get divorced. 


\section{CONDITIONS FOR DOMESTIC AND INTERCOUNTRY ADOPTION}

The domestic adoption is one of the modalities of substitute family described by the Statute on Child and Adolescent (1990). The adoption, however, is an exceptional measure, thus it is necessary to exhaust all the possibilities in order to keep the child in its natural family. If it does not work, the child can still be rise for its extended family. ${ }^{7}$ It is essential that the adoption must offer real advantages for the adopted children and it can be evaluated by the judge and the other professionals involved in the process of adoption. It will be constituted only by sentence, not being allowed adoption by proxy. ${ }^{8}$

There are objective and subjective requirements for the domestic adoption. The objective requirements are present on the Civil Code ${ }^{9}$ I - minimum age of 18 to adopt; II - minimum difference of 16 years between adopter and adopted; III - the dismissal of family power or the free consent of the parents, noting that the Superior Court of Justice understands that an implicit request for family power is not allowed, so that even deferment of adoption does not imply their loss, which must occur in an autonomous procedure, with right to the contradictory. However, it is allowed to cumulate the requests for adoption and removal of family power; IV - when the adopted is a adolescents (twelve years old or more), it is also necessary its consent; V- ; requirement of the probationary period, which can be waived by the judge, with the deadline also stipulated by the court, noting that custody alone does not exempt the stage of coexistence; requirement of the adopter to be registered in the National Registry of Adoption, and compliance with this requirement is not absolute, and may be excepted in favour of the principle of the best interest of the child.

The subjective requirements of adoption are present on the Statute on Child and Adolescent: the real advantages to the minor adopted, which it will be judged based on the principles of proportionality and reasonableness, taking into account the

7 An extended family is the one that includes close relatives to the child or adolescent and maintains ties of affinity. 
relation to adoption, in each concrete case; the legitimate reasons, observing the interest of the minor and the desire of filiations.

In addition, the intercountry adoption is a public order institute that allows a child or adolescent to live in a foreign home. International adoption is exceptional, it happens only after the all the possibilities of adopting a child or adolescent in its own country have been exhausted. The requirements of international adoption are present in Article 51 of the Statute on Child and Adolescent (1990), and are practically the same as those of domestic adoption, except for the intervention of the State and Federal Central Authorities.

According to Cápua (CÁPUA, 2009, pg.109):

\begin{abstract}
The intercountry when it is evidenced through studies that prove that it is in the society in which it was born that it will find it easier to be inserted in a surrogate family, as well as when considering the complexity that surrounds the conflicts of laws in the international adoption, which is not always addressed in opposing theses.
\end{abstract}

\title{
4 PROCEDURES FOR INTERCOUNTRY ADOPTION ${ }^{10}$
}

The norm applicable to adoptions of children and adolescents is the law of the domicile of the child. According to article 51 of the Statute on Child and Adolescent (1990), it is considered intercountry adoption the process by which a person or a couple that habitually resides out of Brazil decides to adopt, following the understanding of the second article of the Convention on Protection of Children and Co-operation in respect of intercountry adoption.

It is important to point out that the main focus of the concept of intercountry adoption aimed at the Statute on Child and Adolescent (1990) and the Hague Convention (1990) is the habitual residence, rather than the nationality of the adopters. Thus, if a Brazilian couple live in the USA and then, they decide to adopt a child in Brazil, it must be made an intercountry adoption, because what matters for the Hague 
Convention is the habitual residence ${ }^{11}$, however, the Brazilians resident abroad have a preference in cases of intercountry adoptions of Brazilian children or adolescents. ${ }^{12}$

The procedure of international adoption begins when the person or couple, when intending to adopt a child, seeks the Central Authority of the State of their habitual residence to be eligible and suited to adopt. After the evaluation of the Central Authority, with the authorization of the person or couple, the latter shall issue a report containing all the data regarding the identity, legal capacity and suitability of the applicant (s) for adoption, such as the situation personal, family and medical, as well as indicate their motives and their ability to adopt by international adoption.

Thus, the document will be sent to the Brazilian Central Authority, accompanied by a psychosocial study prepared by a specialized agency accredited in its country of origin, in addition to a certified copy of the pertinent foreign legislation, with its own validity.

Afterward, the Central Authority will verify the compatibility between the legislation of the Receiving State and the domestic legislation, in addition to analyzing whether the applicant (s) fulfills all the objective and subjective requirements for the approval of the measure, both according to the domestic legislation and that of the Receiving country. After all this procedure, an award of authorization for international adoption will be issued, which will have a validity of one year, and may be renewed, if necessary.

With the possession of the award, the interested party may join the action of international adoption before the Childhood and Youth Court of the forum in which the child or adolescent is.

It is worth noting that the qualification report issued by the State Central Authority does not confer the adopter adoption immediately. First, a judicial process of adoption must be instituted before the Childhood and Youth Court. According to Liberati (LIBERATI, 2009), the applicant will fill petition, along with the qualification

11 The habitual residence of the child and the prospective adoptive parents must be situated in different Contracting States. The concept of habitual residence is not difined and in this respect the Convention follows the tradition of the Hague Conventions such as the 1961 Convention on the Protection of Minors (...). Habitual residence denotes the centre of living of a person and is basically a notion of fact: it is the place where a person has his or her main interests: school, work (...) (VAN LOON, 1993, p. 346).

12 See article $51 \S 2^{\circ}$ of the Statute on Child and Adolescent (1990) 
report issued by the central authority and personal documents, as well as those of the child whose adoption is requested. If there has not been the removal of the family power, the adoptive must join the declaration of the biological parents with consent to adoption.

By assessing international adoption, it is necessary for the judge to verify the occurrence of the coexistence stage and the favourable opinion of the Interprofessional team.

The rite that follows the adoption process is special and the sentence is constitutive, and the participation of the public Prosecutor is indispensable, under penalty of nullity of the deed.

As the judgment has being delivered, the international adoption becomes irrevocable, thus emerging a new bond of affiliation between adoptive and the adopted. The sentence will be registered on the Civil registry, ${ }^{13}$ upon a warrant, which shall contain the information about the new affiliation, cancelling the original registration of the adopted (LIBERATI, 2009).

\section{THE CONTRIBUTION OF MULTIDISCIPLINARY TEAMS}

The reality of the children and adolescents belonging to an institutions of the reception is full of gaps. First, there is a high turnover of employees, the bonds with adults are fragile. There are also no significant personal objects and spaces individualized, inhibiting their self-knowledge and the perception of themselves before the others.

One of the main features of intercountry adoption is the adoption of Children older than two years. Therefore, greater caution is required by the fact that these have been marked by the feeling of abandonment in the face of their biological family, its past childhood, sometimes the whole childhood, passed in institutional welcoming. All these factors interfere in the child's psychic structure, inhibiting the formation of new links.

13 See the article 47 of Statute on Child and Adolescent (1990). 
The challenge is even bigger in intercountry adoption since there is a significant difference. These children change of the country, the environment, the culture. Even the language is different from that they are used to recognized in its social contexts. Thus, the Judiciary getting touch with these children and adolescents, along with the interprofessional team, should place extreme importance on the psychosocial study of adopters and the children so that they can be prepared to deal with the numerous controversies that will be present until the end of the adoption procedure.

The Statute on Child and Adolescent in articles 150 and 151 did not define which professionals would integrate the interprofessional team. However, its objective is to provide advice to the Justice of Childhood and Youth through the preparation of reports or verbally at the hearing. It is also part of the team's work to develop counselling, guidance, referral, prevention and follow-up work under immediate subordination to the judge.

The work of the interprofessional team is of paramount importance, considering the ability to intervene technically outside the legal framework that shows excellent relevance to the final decision of the process, being able to act preventively, detecting any risk factor that may require immediate jurisdictional action.

The intervention of the interprofessional team in adoption procedures is sometimes complex: the team should adopt a multifocal view of the problem and should analyze not only the suitors to adopt, but the children adopted in the future. The purpose of this intervention is simply to verify the social and psychological conditions of those involved in adoption.

The interdisciplinary team role is preponderant before, during and after the adoption process. With regard to the former, the professional psychologist must hold sessions with the interested party to adopt, clarifying possible doubts and questions that they have about the process, as well as promoting a listening environment regarding fears and expectations of the individual or couple with the child who is about to arrive.

During the adoption, the psychologist becomes present in one of the fundamental stages of the process, the so-called preliminary interview, in which a psychosocial study is carried out. Together with the social worker, the psychologist 
assesses whether the foreign adoptive couple has sufficient conditions to build a family environment appropriate to the arrival of a child, whether adoption embodies real benefits for adopting, as well as whether stakeholders are prepared and show compatibility with adoption, even of a different nationality.

In this context, this professional is of paramount importance, as it is who determines the continuity of the adoption process.

The psychologist is also present during the time of coexistence between the child and those interested, and their support may be indispensable, helping adults to promote an adequate environment and the child in the best adaptation to the unknown.

After that process, it is recommended to continue with sessions with the same psychologist who was involved in the process or another who gets access to information from the adoption process. Besides, the psychologist acts as a mediator, through the attempt to help in effective investment in a healthy way and emotional stability, as well as in building trust bonds between the adoptee and the then parents.

\section{POST ADOTIVE CONTROL}

Post-adoption control is carried out by the CEJA or CEJAI of the child's state of origin, utilizing a semiannual report sent by the accredited body that has acted in the adoption process or by the Central Authority of the host country for a minimum period of two years. In case the child has not yet acquired the nationality of the host country, the reports will continue to be sent with a copy to the ACAF, pending the acquisition of nationality. ${ }^{14}$

In order to prepare this report, the Secretariat for Human Rights provides a report model that has fields related to the identification, methodology used, aspects regarding the development of the child or adolescent and family, as well as the conclusion of the professional who performed the report, whether a psychologist, be a social worker (BRAZIL, 2014). 


\section{SCOPE OF THE 1993 HAGUE CONVENTION}

It is essential to understand the reasons why the Hague Convention on Protection of Children and Co-operation in Respect of Intercountry Adoption is one of the Conventions that counts the most significant number of States that have ratified or adhered..$^{15}$ It can be explained by the main focus of the Convention on international legal cooperation. Under this perspective, article 17 of the Convention has a critical role, because it connects the Central Authority of the State of origin to the Central Authority of the receiving country. This article stipulated a requirement list that ensures that adoptions are made in respect to the children's protection and welfare.

The focus is on the children who were neglected by their State instead of the prospective parents. Even the Brazilian and the foreigners adopters believe that the main purpose of the adoption is to protect the best child interest (VARGAS, ROSA, AGLIO, 2014).

Under this perspective, the Convention has three aims: the adoptees' protection, the network of legal cooperation among the Contracting States and the validity of adoption decrees in the other Contracting States ${ }^{16}$. Therefore, it is clear that the Convention protect the best interest of the children and adolescents through a cooperation mechanism.

For instance, the adoption will happen if the Central Authorities of both States have agreed that the adoption may proceed and the prospective adoptive parents are eligible and suited to adopt and the child is or will be authorized to enter and reside permanently in the receiving State. ${ }^{17}$ These requirements amplify the protection and welfare of the child, avoiding situations that could go against the best interest of the child. Also, it means that the two Central Authorities need to share responsibilities for the adoption. Therefore, the key to the success of the Convention is the cooperation between the two countries since the beginning of the process. The Convention proposes supervising mechanisms between the two Central Authorities and discourage ill-prepared adoptions avoiding disruption and abuses such as "the 
abduction ${ }^{18}$, the sale ${ }^{19}$ of or traffic in children ${ }^{20 "}$. (VAN LOON, 1993, p.344). For this reason, the Convention is essential to prevent crime in spite of not posing criminal sanctions. Thus, if the adoption follows all the rules presented in the Convention the chances of child abduction, selling of and trafficking in children are reduced significantly.

The cooperation mechanisms also provide a better quality of the match between the child and his or her future family. It happens because it emphasizes the careful preparation of the family of origin and the receiving State. Consequently, the chances of the adoption failing, later on, are reduced.

Another example of cooperation mechanisms, instead of revoking the law of the State of Origin, the Hague Convention aims that the nation law should be respect by the prospective parents. ${ }^{21}$ Therefore, the Statue on Child and Adolescent and the Civil Code (2002) has to be observed by anyone who desires to adopt in Brazil (2004, MARQUES, p.496). This kind of perspective helps to increase the numbers of ratifying States of the Convention.

\subsection{THE 1993 HAGUE CONVENTION AS A HUMAN RIGHTS INSTRUMENT}

Nowadays, the international private law is concerned in implementing new principles and more flexible rules to expand the human rights values already known in the international legal order (ARAUJO, 2004, p.576). According to Araujo: "The protection to the human dignity and its principles has the goal to influence the application of international law through the own methodology of the International private law" (ARAUJO, 2004, p.576)

18 There are also many reports of outright abduction of children playing in the Yard, returning from school or even being snatched from the arms of their mother. (VAN LOON, 1993, p.253)

19 There are frequent reports of parents giving up their child for adoption in return for a specific, often minimal sum of money - for example, out of fear that the child would die of hunger if it remained with them. There are also reports of one parent selling a child without the other parent's knowledge. (VAN LOON, 1993, p.253).

20 Often child trafficker is part $f$ extensive networks. In some countries lawyers and notaries, social workers (even in some cases those appointed by the courts), hospitals, doctors, children's institutes (sometimes turned into complete "baby farms") and others work together to obtain children and make profit out of the despair of parents, in particular women, in difficult situations, sometimes by deceiving them. (VAN LOON, 1993, p.253)

21 See Article 28 of the Convention 
The importance of human rights, therefore, has been increasing in the international private law scenario. In this respect, despite the fact the Hague Convention on Protection of Children and Co-operation in Respect of Intercountry Adoption is not easy to characterize regarding types of Conventions, Van Loon claims the human rights nature of the 1993 Hague Convention. However, there are some particularities in this Convention that differentiates this Convention to other instruments of human rights protection (VAN LOON, 1993, p.335).

Most international human rights instruments aimed at protecting rights in the context of just one domestic legal order, however, the 1993 Hague Convention focuses on a transnational phenomenon. The biggest concern of the 1993 Hague Convention is to protect the movement of children from one country ("The State of origin") to another ("receiving State") for purposes of adoption. ${ }^{22}$ It is important to say that the Convention aims the protection of the child's best interest through a unique "horizontal" monitoring system. Under this system, each intercountry adoption needs to be monitored for the Central Authorities of the State of Origin and the receiving state. Besides, the Central Authorities supervise the activities of each other, increasing the protection of the child's best interest. ${ }^{23}$

Moreover, there are other ways of looking at the 1993 Hague Convention. The second one is to see it as an instrument for judicial and administrative cooperation in matters of private law. As it was approached above, the 1993 Hague Convention stipulates co-operation rules to the State of origin and the receiving State by determining the minimum requirements be respected before any intercountry adoption take place (VAN LOON, 1993, p.337).

The third way of looking at it as an instrument of reducing conflicts of jurisdiction or applicable law on intercountry adoption as the 1984 Inter-American Convention. However, Van Loon points out the following:

22 See Article 2.1 of the Convention. The international adoption, for the Convention, occurs when a child habitually resident in one Contracting State ("the State of origin") has been, is being, or is to be moved to another Contracting State to be adopted by a person habitually resident in the "receiving State."

23 See Article 1.a) of the Convention 


\begin{abstract}
Instead of attempting to classify the Convention exclusively under one of these three categories, it would seem more helpful to bring the Convention, as a multi-dimensional instrument, under all of them. As a matter of fact, private international law is becoming increasingly permeated by elements of judicial and administrative co-operation and, likewise, the fields of human rights and private international law are touching more and frequently. The Convention is the fruit of this new development and, in order to be well understood, it should be looked at with a mind aware of the increasing significance of international co-operation for the unification of private international law and the growing interaction between human rights and private international law (VAN LOON, 1993, p. 338).
\end{abstract}

In spite of the 1993 Hague Convention being a differentiated instrument of human rights protection, it still has importance in protecting the best interest of the child. Since the signing of the Convention, many adolescents and children had the opportunity to find a family in which they can be loved and care. According to the number of ACAF (Federal Central Authority in Brazil), 5.796 (five thousand, seven hundred and ninety-six) children and adolescents were adopted through the 1993 Hague Convention between 1999 and 2017 in Brazil, following all the procedure explained above.

\title{
8 BRIEF ANALYSIS OF STATISTICS ON INTERNATIONAL ADOPTIONS IN BRAZIL
}

The best way to demonstrate how the application of the Hague Convention on Adoption 1993 contributes to promoting international adoption in Brazil is through the numbers collected in the official bodies. Therefore, it is proposed to analyze some data below between 1999 - when the Convention entered into force in Brazil - and 2017.24

24 It is important to register that one of the author, the undergraduate student Diogo Alexandre de Freitas, has collected and organized these statistic data as part of a research project on international legal cooperation means applied to family issues in the field of private international law, supervised by the professor Marcos Vinícius Torres also author, at the Law School of the Federal University of Rio de Janeiro. Mr. de Freitas was granted a research scholarship from the Brazilian Ministry of Education for it, throughout the academic year 2018. 


\subsection{METHODOLOGY}

It is important to register that any official body can organize the data about intercountry adoption in Brazil. Thus, it was necessary to establish contact to the Federal Central Authority (ACAF) and the local authorities (CEJAs/CEJAIs) to systematize the data of intercountry adoption between the years 1999 and 2017. In the beginning, it was sending a letter to all the twenty-seven Courts of Justice through the states Central Authorities ${ }^{25}$ (CEJAs/CEJAls) asking about the number of intercountry adoption in that specific state between 1999 and 2017. Besides, it was necessary to ask about intercountry adoptions to the Federal Central Authority (ACAF) through an administrative process.

The main focus of the research was to trace a profile of the adopters and adopted children in Brazil. Therefore, it was asked to the Central Authorities to split the intercountry adoptions into the following categories: a) Independent adoptions/ agency adoptions; b) the age of the adopted children; c) the receiving country; d) same-sex adopters/ straight couple; d) the gender of the adopted children.

\subsection{ACAF NUMBERS}

The first aspect to be analyzed is the number of international adoptions celebrated in Brazil and its distribution by gender, as shown below:

25 The twenty-seven Court of Justice in Brazil are located in the following states: the State of Acre, State of Alagoas, State of Amapá, State of Amazonas, State of Bahia, State of Ceará, Distrito Federal (Federal District), State of Espírito Santo, State of Goiás, State of Maranhão, State of Mato Grosso, State of Mato Grosso do Sul, State of Minas Gerais,State of Pará, State of Paraíba, State of Paraná, State of Pernambuco, State of Piauí, State of Rio de Janeiro, State of Rio Grande do Norte, State of Rio Grande do Sul, State of Rondônia, State of Roraima, State of Santa Catarina, State of São Paulo, State of Sergipe and State of Tocantins. 


\begin{tabular}{|c|c|c|c|c|}
\hline \multicolumn{5}{|c|}{ Intercountry adoption in Brazil by gender } \\
\hline Year & male & female & not informed & total \\
\hline 1999 & 275 & 177 & - & 452 \\
\hline 2000 & 194 & 141 & - & 335 \\
\hline 2001 & 197 & 134 & 5 & 336 \\
\hline 2002 & 192 & 156 & 3 & 351 \\
\hline 2003 & 250 & 170 & 2 & 422 \\
\hline 2004 & 260 & 177 & 5 & 442 \\
\hline 2005 & 201 & 150 & 27 & 378 \\
\hline 2006 & 146 & 120 & 66 & 332 \\
\hline 2007 & 92 & 61 & 161 & 314 \\
\hline 2008 & 212 & 173 & 15 & 400 \\
\hline 2009 & 231 & 185 & 15 & 431 \\
\hline 2010 & 159 & 157 & 1 & 317 \\
\hline 2011 & 178 & 157 & - & 335 \\
\hline 2012 & 161 & 139 & - & 300 \\
\hline 2013 & 122 & 95 & - & 217 \\
\hline 2014 & 65 & 61 & - & 126 \\
\hline 2015 & 67 & 48 & - & 115 \\
\hline 2016 & 61 & 54 & - & 115 \\
\hline 2017 & 46 & 32 & - & 78 \\
\hline TOTAL & 3109 & 2387 & & 5796 \\
\hline
\end{tabular}

It is clear that intercountry adoptions in Brazil have had a peak in the 2000s, with the consistent application of the Convention. In the last years, the number of international adoptions decreased, probably because of the competition with other foreign centers for international adoption and due to the expansion of surrogacy centers. Furthermore, the number of intercountry adoptions in which the ACAF could not inform the gender of the children is alarming, especially in 2007 when more than half of the adoptions the Federal Central Authority were not able to give quality information.

It is also notable that more male minors are often adopted than female minors. However, it is important to say that the most prospective parents do not make any restrictions when they pretend to adopt foreign children. Thus, this number cannot be interpreted as a preference of the adopter to adopt male children ${ }^{26}$. It represents that more male children are available for adoption in Brazil, considering the subsidiary

26 In many parts of the world; it is the exact opposite that happens. Boys are usually preferred to girls. Girls are often difficult to place for adoption (VAN LOON, 1993, p. 226). 
character of international adoption since the national adopters prefer to adopt girls. Around $30 \%$ of the national couples waiting at the Nation Register of adoption only pretend to adopt female child. ${ }^{27}$ On the other hand, just $8 \%$ of the national couples would just adopt male child.

In addition, the Nation Register of adoption demonstrated that the prospective parents on the intercountry adoption do not make many restrictions. In general, there is no preference of race, gender and the majority accepts to adopt older children (8 10 years old or less). ${ }^{28}$

\begin{tabular}{|c|c|c|c|c|c|c|c|c|}
\hline \multicolumn{8}{|c|}{ Intercountry adoption in Brazil by Receiving Country } \\
\hline \multirow{2}{*}{ Year } & \multicolumn{9}{c|}{ Receiving Country } \\
\cline { 2 - 10 } & Italy & France & Spain & USA & Norway & Germany & Netherlands & others \\
\hline 1999 & 139 & 108 & 28 & 47 & 9 & 17 & 27 & 77 \\
\hline 2000 & 125 & 73 & 25 & 20 & 9 & 15 & 38 & 30 \\
\hline 2001 & 127 & 95 & 27 & 12 & 10 & 9 & 29 & 27 \\
\hline 2002 & 138 & 97 & 30 & 11 & 23 & 12 & 20 & 20 \\
\hline 2003 & 208 & 94 & 29 & 20 & 29 & 11 & 24 & 7 \\
\hline 2004 & 213 & 87 & 24 & 44 & 14 & 16 & 31 & 13 \\
\hline 2005 & 207 & 72 & 17 & 41 & 2 & 8 & 26 & 5 \\
\hline 2006 & 197 & 57 & 10 & 30 & 3 & 11 & 11 & 13 \\
\hline 2007 & 225 & 31 & 16 & 18 & 13 & 5 & 4 & 2 \\
\hline 2008 & 348 & 38 & 0 & 0 & 11 & 2 & 0 & 1 \\
\hline 2009 & 304 & 64 & 18 & 28 & 7 & 2 & 0 & 8 \\
\hline 2010 & 268 & 17 & 6 & 18 & 8 & 0 & 0 & 0 \\
\hline 2011 & 282 & 19 & 14 & 13 & 5 & 1 & 0 & 1 \\
\hline 2012 & 261 & 12 & 5 & 9 & 6 & 2 & 0 & 5 \\
\hline 2013 & 180 & 15 & 2 & 13 & 2 & 0 & 0 & 5 \\
\hline 2014 & 97 & 15 & 4 & 8 & 0 & 0 & 0 & 2 \\
\hline 2015 & 90 & 18 & 1 & 6 & 0 & 0 & 0 & 0 \\
\hline 2016 & 92 & 9 & 2 & 12 & 0 & 0 & 0 & 0 \\
\hline 2017 & 57 & 10 & 1 & 9 & 0 & 0 & 0 & 1 \\
\hline Total & 3558 & 931 & 259 & 359 & 151 & 111 & 210 & 217 \\
\hline & & & & & & & & \\
\hline
\end{tabular}

The second aspect to be analyzed is the destiny of intercountry adoptions celebrated in Brazil:

It is possible to notice above that there is a significant movement of children from Brazil (developing country) to Italy, France, Spain, United States of America (developed countries) for purposes of adoption. This phenomenon usually occurs all around the world; many authors could classify Brazil as a "source country" because of 
the continuous fluctuations of the children to other countries. It can be easily explained. Typically, the developing countries have difficulties to feed and care the orphaned children or finding a foster family inside the country. Thus, the solution is to surrender these children to intercountry adoption. On the other hand, the difficulties of adopting a child in developed countries are well-known, so the prospective parents search the intercountry adoption.

The last item to be examined is the contribution of the adoption agencies; as predicted and controlled concerning the Hague Convention on Adoption 1993, as shown below:

\begin{tabular}{|c|c|c|c|}
\hline \multicolumn{5}{|c|}{ Independent and Agency adoptions in Brazil } \\
\hline Year & Independent Adoption & Agency Adoption & total \\
\hline 1999 & 411 & 25 & 452 \\
\hline 2000 & 271 & 64 & 335 \\
\hline 2001 & 233 & 103 & 336 \\
\hline 2002 & 204 & 147 & 351 \\
\hline 2003 & 296 & 126 & 422 \\
\hline 2004 & 346 & 96 & 442 \\
\hline 2005 & 286 & 92 & 378 \\
\hline 2006 & 279 & 53 & 332 \\
\hline 2007 & 239 & 75 & 314 \\
\hline 2008 & 46 & 354 & 400 \\
\hline 2009 & 60 & 371 & 431 \\
\hline 2010 & 21 & 296 & 317 \\
\hline 2011 & 27 & 308 & 335 \\
\hline 2012 & 14 & 286 & 300 \\
\hline 2013 & 20 & 197 & 217 \\
\hline 2014 & 38 & 88 & 126 \\
\hline 2015 & 17 & 98 & 115 \\
\hline 2016 & 6 & 109 & 115 \\
\hline 2017 & 0 & 78 & 78 \\
\hline
\end{tabular}

It is a tendency in many countries to discourage independent adoptions and to promote the intermediary services of adoptions agencies because it is safer, faster and protect the best interest of children and adolescents. This table above shows that Brazil has been following the global tendency on promoting the intercountry adoptions 
through accredited bodies. However, it is important to point out that the Convention stipulates the minimum standards for the agencies to work ${ }^{29}$.

Besides, the Convention and the Children's and Adolescent's Act 1990 are concerned over irregular practices - in particular, profit-making ${ }^{30}$. In conclusion, it is easy to notice how the implementation of the Convention in Brazil contributed to promoting the use of the intermediate services of specialized agencies; ${ }^{31}$ To achieve regular adoptions. From the late 2000s on, it is clear that there is a predominance of the use of adoption agencies for international adoptions in Brazil. The Convention introduced the culture of the use of adoption agencies in Brazil, which was almost unknown before the Convention, as it ensured they could be trustful.

\section{CONCLUSION}

As it was observed, the scenario of domestic and international adoption has changed completely after the Statute on Child and Adolescent (1990). On the whole, it is possible to say that before these the Statute on Child and Adolescent and the Hague Convention 1993, there was a lack of systematic records and absence of a central authority to control the intercountry adoption practices. The creation and consolidation of the state Central Authorities for International Adoption, as well as the Federal Central Authority and the implementation of the National Registry of Adoption considerably attenuated this problem that involved international adoption in Brazil.

Thus, in the course of the elaborated reflection, it was defended the direct action of the central authorities and the Judicial Commissions of International Adoption, to actively regulate the process of international adoption, step by step. For, according to Statute on Children and Adolescents (1990), establishing the placement of a child in a foreign surrogate family, should be considered an exceptional measure, as a last resort, due to the significant risk of international trafficking of minors.

29 See chapter III of the Convention

30 See article 52-A of Children's and Adolescents' Act 1990

31 See Articles 10-12 of the Convention; for accredited bodies; such as agencies, for supporting international adoption. 
It is important to say that the Convention aims the protection of the child's best interest through a unique "horizontal" monitoring system. Under this system, each intercountry adoption needs to be monitored for the Central Authorities of the State of Origin and the receiving state. Besides, the Central Authorities supervise the activities of each other, increasing the protection of the child's best interest.

It is believed that intercountry adoption can and should be a measure used to reduce the number of abandoned children and consequently their marginalization, especially in Brazil, however, the whole process of international adoption must be strictly observed before, during and after adoption. Maybe the possibility of adoption by same-sex couples, which is quite recent to some countries, could be a chance for many abandoned children in Brazil to find a home abroad where they can be care and loved.

\section{REFERENCES}

ARAUJO, N. Direito Internacional Privado: teoria e prática brasileira. Rio de Janeiro: Renovar, 2003.

BRAZIL. ADI - 4.277-DF and ADPF no132- $R$ J. 2011. Available on < http://redir.stf.jus.br/paginadorpub/paginador.jsp?docTP=AC\&doclD=628635>

BRAZIL. Cadastro Nacional de Adoção. 2008. Available at: < http://www.cnj.jus.br/cnanovo/pages/publico/index.jsf>.

Lei no 12.010, de 3 de agosto de 2009. Available at: http://www.planalto.gov.br/ccivil 03/ Ato2007-2010/2009/Lei/L12010.htm.

Ministério de Justiça e Segurança Pública. Grupo de Trabalho do Conselho das Autoridades Centrais Brasileiras para elaboração, harmonização e revisão dos Modelos de Relatórios pós-adotivos de crianças. 2014. Available at: $\quad$ https://www.justica.gov.br/sua-protecao/cooperacao-internacional/adocaointernacional/arquivos/modelo-de-relatorio-pos-adotivo-aprovado-em-28-03-2014.pdf

Secretaria Especial de Direitos Humanos. Available at: http://www.sdh.gov.br/assuntos/criancas-e-adolescentes

Superior Tribunal de Justiça. Recurso Especial 889.852, Relator Ministro Luis Felipe Salomão, J. 27/04/2010. 
Andrighi, J. 18/12/2012.

Recurso Especial 1.281.093-SP, Relator Ministro Nancy Recurso Especial 1.540.814, Relator Ministro Villas Bôas Cueva,

J. 18/08/2015a. Supremo Tribunal Federal. Ação Direta de Constitucionalidade 4.277 e Arguição de Descumprimento de Preceito Fundamental no132, J. 05/05/2011.

Lúcia, J. 05/03/2015b.

Recurso Extraordinário 846.102/PR, Relator Ministro Carmén

CÁPUA, V. A. Adoção Internacional: Procedimentos Legais - Conforme a Nova Lei de Adoção Lei 12.010/09. Curitiba: Juruá, 2009

HCCH. 33: Convention of 29 May 1993 on Protection of Children and Co-operation in Respect of Intercountry Adoption. 1995. Available at: https://www.hcch.net/en/instruments/conventions/status-table/?cid=69

LIBERATI, W. D. Adoção Internacional doutrina e jurisprudência. $2^{\underline{a}}$ edição. São Paulo: Malheiros, 2003.

MACEDO, F. História da Adoção Internacional de Crianças: um perfil franco-brasileiro (1990-2006). In Anais do XXVI Simpósio Nacional de História, 2011.

MARQUES, C.L. A Convenção de Haia de 1993 e o regime de adoção no Brasil após a aprovação do novo Código Civil Brasileiro em 2002. In Revista de Cadernos do Programa de Pós-Graduação em Direito, Volume, Número 4, 2004.

MERÇON-VARGAS, E. A., Rosa, E. M., \& Dell'Aglio, D. D. Adoção nacional e internacional: Significados, motivações e processos de habilitação. In Revista da SPAGESP, 15(2), 12-26, 2014.

OLIVEIRA, H. F. Adoção: aspectos jurídicos, práticos e efetivos. 2ำ edição. São Paulo: Mundo Jurídico, 2017.

VAN LOON, H. International Co-Operation and Protection of Children with Regard to Intercountry Adoption. In Recueil des cours de l'Académie de Droit International de la Haye. vol. 244,1993. 